\title{
Performance of tasks related to state security in the European Union conditions by the President of the Republic of Poland
}

Keywords: President of the Republic of Poland, tasks of the President of the Republic of Poland, state security, European Union

Abstract: The subject of the article is to consider the theoretical and practical possibilities of the President of the Republic of Poland to perform his constitutional tasks in the area of state security. The presented analysis takes into account the legal and institutional conditions resulting from Poland's membership in the European Union.

Membership in the European Union (EU) results in the evolution of the constitutional system of government in Poland, e.g. by changing the systemic position of the supreme organs of state authorities. This is mainly a consequence of delegating some of the competences of these organs to an international organization ${ }^{1}$. The functioning of the state in the EU institutional and legal system also influenced the political position of the president of the Republic of Poland. This position can be determined by analyzing the possibilities of implementing the president's constitutional tasks, taking into account the EU conditions

* ORCID ID: https://orcid.org/0000-0003-2598-2867; professor at the Institute of Political Science, University of Warmia and Mazury in Olsztyn. Email: waldemar.tomaszewski@ uwm.edu.pl.

1 W. Tomaszewski, Władza wykonawcza $w$ Polsce z perspektywy funkcjonowania państwa $w$ Unii Europejskiej. Pomiędzy normatywizmem a realizmem, Olsztyn 2015; J. Jaskiernia, Funkcje Konstytucji RP w dobie integracji europejskiej i radykalnych przemian politycznych, Torun 2020. 
set out in the acquis communautaire. These considerations focus on the potential and real possibilities of the President of the Republic of Poland to perform his constitutional tasks in the field of state security.

One of the basic constitutional tasks of the president is "to protect the sovereignty of the state and the inviolability and indivisibility of its territory" 2 . This provision obliges the President of the Republic of Poland, inter alia, to care for the unitarity of the territory of the Polish state and to counteract attempts to change the territorial system, e.g. by separating part of the territory or introducing autonomy.

In this aspect, it should be noted that the President of the Republic of Poland does not have any instruments that could be applied directly to the EU, its institutions and member states ${ }^{3}$. Seemingly, due to the membership criteria set out in the Treaty of European Union and the so-called Copenhagen criteria, the occurrence of threats to the integrity of a member state within the EU political system is unlikely, however, as part of the polistrategy and safeguarding the interests of the state, it would be required to specify the competences of the President of the Republic of Poland in this field ${ }^{4}$.

The EU law does not regulate the territorial integrity of its Member States. Moreover, practice also shows that the EU institutions do not have the power to make decisions in matters relating to the inviolability and integrity of the territories of the Member States. Yet, even more important question seems to be - how, in such EU conditions, can the President of the Republic of Poland effectively fulfill his constitutional obligations?

Considering the potential possibilities of implementing the activities of the President of the Republic of Poland in the analyzed aspects of state security, the following may be indicated:

1) ratification of an international agreement and initiating the control of EU law in terms of its compliance with the Constitution of the Republic of Poland of 1997;

2 Art. 126, the Constitution of the Republic of Poland of $2^{\text {nd }}$ April 1997, Dz.U. of 1997, no. 78, pos. 483 with amendmends; T. Słomka, Prezydent Rzeczypospolitej po 1989 roku. Ujecie porównawcze, Warsaw 2005.

3 Further see: M. Grzybowski, Władza wykonawcza w Rzeczpospolitej Polskiej w warunkach członkostwa w Unii Europejskiej (wybrane zagadnienia), [in:] M. Kruk, J. Wawrzyniak (eds.), Polska $w$ Unii Europejskiej, Warsaw 2005, pp. 22-23; R. Piotrowski, W sprawie kompetencji Prezydenta $R P$ „w stosunkach zewnętrznych”, [in:] J. Wawrzyniak, M. Laskowska (eds.), Instytucje prawa konstytucyjnego $w$ dobie integracji europejskiej, Warsaw 2009, p. 220.

4 The issue of sovereignity in context of the tasks of the President of Poland as stated in art. 126 section 2 of the Constitution, was analysed by the Constitutional Tribunal in its verdict of $11^{\text {th }}$ of May 2005, files number: K 18/04 (OTK ZU no. 5/A/2005, pos. 49). 
2) direct participation of the President of the Republic of Poland in the work of EU institutions;

3) other, normative and non-normative actions of the President of the Republic of Poland in the EU political system.

In reference to point 1 - the constitutional duty of the President of the Republic of Poland to "guard" the sovereignty of the state is also carried out by ratifying and initiating the control of the compliance of EU treaties with the Constitution of the Republic of Poland of 19975. These powers of the President of the Republic of Poland allow him to protect Polish constitutional values within European Union.

In case of ratification of international agreements, the President may potentially have a significant influence on the conduct of foreign policy. There are opinions that the President of the Republic of Poland may refuse or postpone ratification. Ratification is the right, not the president's duty. However, there are also other opinions that the President of the Republic of Poland is obliged to ratify international agreements concluded by the Council of Ministers when it submits such a request. Moreover, when there is a previously adopted law expressing consent to the ratification, the obligation of the President of the Republic of Poland becomes even more categorical, and a possible president's veto should be considered ineffective ${ }^{6}$.

Thus, if the President vetoed a bill, then "the president would influence the exercise of his constitutional powers in the field of ratification and instead of limiting the powers, the constitution expands the president's field of activity" and only in relation to agreements requiring statutory authorization to ratify ${ }^{7}$. On the other hand, the reason for refusing to ratify should be based on the unconstitutionality of such an international agreement.

5 Further: M. Grzybowski, Role ustrojowe Prezydenta RP $w$ kontekście członkostwa $w$ Unii Europejskiej, «Państwo i Prawo» 2004, no. 7, pp. 5-11; M. Kruk, Tryb przystapienia Polski do Unii Europejskiej $i$ konsekwencje członkostwa dla funkcjonowania organów państwa, [in:] K. Wójtowicz (ed.), Otwarcie Konstytucji RP na prawo międzynarodowe i procesy integracyjne, Warsaw 2006, p. 136.

$6 \quad$ K. Spryszak, Wyrażenie zgody na ratyfikacje umowy międzynarodowej - model konstytucyjny $i$ uwarunkowania jego realizacji, «Przegląd Konstytucyjny» 2019, no. 3, pp. 83-84; B. Banaszak, Ratyfikacja umowy międzynarodowej, [in:] W. Skrzydło, P. Grabowska, R. Grabowski (eds.), Konstytucja Rzeczypospolitej Polskiej. Komentarz encyklopedyczny, Warsaw 2009, p. 490; L. Garlicki, Polskie prawo konstytucyjne. Zarys wyktadu, Warszawa 2019, p. 294 and following pages.

7 R. Stemplowski, O konstytucyjnym pojęciu prowadzenia polityki, «Przegląd Sejmowy» 2007, no. 4 , p. 243. 
The ratification process may be completed or stopped if the President of the Republic of Poland refuses to sign it. This is not possible in the case of statutes whose compliance with the Constitution has been previously confirmed by the Constitutional Tribunal ${ }^{8}$. Practice has shown that this is a significant systemic problem. It should be emphasized that the ratification process of the Treaty of Lisbon was clearly slowed down by the lack of the signature of the President of the Republic of Poland. By a resolution of 23 January 2009, the Sejm asked the President of the Republic of Poland to "take into account the will of both chambers of parliament and complete the ratification process of the Treaty of Lisbon ${ }^{9}$ as soon as possible".

The competences of the President of the Republic of Poland also include initiating the control of compliance of the acts of primary EU laws with the Constitution of the Republic of Poland of 1997. This may be an important element in the performance of tasks related to state security by the President of the Republic of Poland.

The President of the Republic of Poland, as a party constitutionally authorized to ratify concluded international agreements, especially before its execution, should assess the submitted agreement from the point of view of coherence with the requirement to protect the sovereignty of the state, as well as with the provisions of the Constitution of the Republic of Poland of 1997. The President of the Republic of Poland is the authority constitutionally obligated to do so. Thus, the examination of the agreement submitted for ratification from the point of view of state sovereignty is not only a right, but a constitutional obligation of the President of the Republic of Poland. This obligation also applies to any contract that revises or supplements previous treaties ${ }^{10}$.

Pursuant to the Constitution of the Republic of Poland of 1997, the President of the Republic of Poland may refer any international agreement to the Constitutional Tribunal. Another competence that the President of the Republic of Poland has in the legislative process is to raise objections to a legislative act. In connection with the method of implementation of EU law adopted in Poland, the act is an act of internal

8 L. Mażewski, Prowadzenie polityki zagranicznej w Rzeczypospolitej Polskiej, «Ruch Prawniczy, Ekonomiczny i Socjologiczny» 2009, no. 3, p. 16.

9 The law allowing for the consent on ratification of the Treaty of Lisbon was approved on $1^{\text {st }}$ of April 2008. See: Rezolucja Sejmu Rzeczypospolitej Polskiej z dnia 23 stycznia 2009 r. w sprawie jak najszybszego ratyfikowania Traktatu z Lizbony (M. P. 2009, no. 6, pos. 64).

10 M. Grzybowski, Role ustrojowe Prezydenta RP w kontekście członkostwa w Unii Europejskiej, «Państwo i Prawo» 2004, no. 7, p. 7. 
law by means of which the norms of EU law are introduced into the Polish legal system. With regard to each act, including the implementing act, the President of the Republic of Poland may exercise his powers, i.e. a suspensive veto or a motion to the Constitutional Tribunal.

At this point, however, attention should be drawn to an important, but yet unresolved problem of constitutional control of acts of secondary law enacted by EU institutions. Moreover, there is also no clear definition of the powers with which the President of the Republic of Poland can react in cases when the EU bodies intrude into the spheres of not delegated powers and invoke the principle of the primacy of laws. These problems may disturb the President of the Republic of Poland in fulfilling his constitutional obligations.

In reference to aspect 2, it is assumed that the political position of the President of the Republic of Poland as "the supreme representative of the Republic of Poland" differs from the function of "the representative of the state in foreign relations" and the "guarantor of the continuity of state power". Moreover, these tasks are carried out by the President of the Republic of Poland in cooperation with other organs of state authority, and the President of the Republic of Poland does not have exclusive sovereignty over any of them. Moreover, the president cannot fulfill these tasks freely. These conditions also apply to the EU aspect.

The president does not have the power to conduct Polish foreign policy independently, as provided for in the constitution. Its management is the responsibility of the Council of Ministers. This category of matters may include relations between Poland and the European Union. However, they do not constitute a classically understood foreign policy, as in many areas they refer to tasks carried out as part of internal policy.

The performance of some of the tasks and powers of the Council of Ministers requires normative cooperation with the President of the Republic of Poland. However, with regard to the tasks of the President, the requirements to cooperate with the Prime Minister and the competent ministers are executed in a much wider extent. For example, the duty to cooperate in the field of foreign policy rests primarily, but not exclusively, with the President of the Republic of Poland. The president is also forced to refrain from actions in the EU aspect, which he had not discussed earlier with the Prime Minister or the Minister of Foreign Affairs. These norms mean that the President of the Republic of Poland is obliged to seek compromises with the Council of Ministers and its president. Thus, there is no complete balance regarding the scopes of the constitutional obligation to cooperate. This significantly 
reduces the political position of the President of the Republic of Poland in $\mathrm{EU}$ conditions.

The obligation of cooperation between state authorities also means maintaining uniformity of action in the field of relations with the EU, and its aim is to prevent the creation of two independent decision-making centers on European matters. Thus, the President of the Republic of Poland cannot pursue a policy that competes with the policy established by the government and in the EU and its institutions to take a position contrary to one represented by the government.

The President of the Republic of Poland is engaged in the sphere of European politics, but only to a limited extent. This can be seen in the possibility of his participation and role in the European Council. The possible participation of the president in the European Council is not limited to representation, but involves consensus decisions by this institution and is associated with political consequences. It should be taken into account that the European Council is the only body in the EU system in which the President of the Republic of Poland can actually participate. The European Council is made up of 'heads of state or government' depending on the systems of government defined in the Member States. Other institutions have a strictly defined composition and mode of operation. Thus, the potential performance of constitutional tasks by the President of the Republic of Poland in the institutional system of the EU may only take place within the European Council. Therefore, there are opinions that the political position of the President of the Republic of Poland excludes the possibility of making his participation in the sessions of the European Council dependent on the consent of another body, in particular the Prime Minister, or treating the President of the Republic of Poland as "a person accompanying the government delegation". The European Council is the only EU body in which the President of the Republic of Poland may appear.

However, the possible presence of both the President of the Republic of Poland and the Prime Minister at a session of the European Council may be perceived as a failure to define the principle of representation and the principle of precedence. Therefore, it is assumed that since the European Council has been defined as a forum where the Member States are represented primarily by a person participating in state governance, the prime minister of the Polish government has priority in its meetings. This is a consequence of the rationalized version of the parliamentary-cabinet model adopted in the Polish Constitution of 1997. However, as a consequence of unequivocally granting the Prime Minister 
the decision to participate in the European Council and determining the composition of the delegation, the political position of the President of the Republic of Poland is weakened, as nothing is clear about his participation in these meetings. The practice has revealed potential conflicts within the executive branch in this respect.

However, the political position of the President of the Republic of Poland changes when the European Council takes up issues that may have consequences for Poland's sovereignty and security. Such a circumstance would justify the participation of the President of the Republic of Poland in the European Council in order to perform his constitutional tasks in this area. It can be assumed that in this case the right of the President of the Republic of Poland to participate in "EU summits" becomes unambiguous. The problem, however, is the definition of the category of "security" and the possibility of a broader understanding of it.

Regarding aspect 3, the political position of the President of the Republic of Poland in terms of the functioning of the state in the EU is also weakened by the fact that the President has no exclusive rights to implement such tasks solely. For example, in the field of ensuring the observance of the constitution, the tasks of the president are supplemented by the Constitutional Tribunal, and in terms of guarding the inviolability of the territory - by the Council of Ministers and the Minister of National Defense. Another example is the adoption of a law ratifying an international agreement, which is made at the request of the Council of Ministers. Also, the appointment and dismissal of plenipotentiary representatives of the Republic of Poland, or the acceptance of credentials requires cooperation with the Minister of Foreign Affairs.

In the EU reality, the President of the Republic of Poland remains the supreme representative of the Republic of Poland. However, in the European Council, Polish affairs are handled by the Prime Minister. Functioning in the EU does not change the task of the President of the Republic of Poland to guarantee the continuity of state power. The task of ensuring compliance with the Constitution of the Republic of Poland and of guarding the sovereignty and security of the state as well as the inviolability and integrity of its territory, which the President of the Republic of Poland does through cooperation with the Constitutional Tribunal and in consultation with the Prime Minister, with whom he is obliged to coordinate his position and activities, remains the same in the EU area. Moreover, the area of European affairs is more and more often treated as internal policy, which reduces the president's powers. The president grants Polish citizenship and agrees to renounce it, and 
it should be taken into account that the acquisition of Polish citizenship means the adoption of EU citizenship.

As part of performing his constitutional tasks, taking into account the conditions of the functioning of the state in the EU, the President of the Republic of Poland may also refer to broadly understood security. The issues of relations between the Polish state and the EU and the role and significance of the President of the Republic of Poland have evolved since the accession in 2004. The current importance of these relations and the priorities of the President of the Republic of Poland are visible in the latest National Security Strategy of the Republic of Poland, approved by the President of the Republic of Poland in May 2020. The Strategy takes into account, inter alia, the context of Poland's presence in the European Union, and the National Security Bureau received guidelines during the work on the Strategy, as to the directions of activities of the President of the Republic of Poland in the field of state security. The initiative of the President of the Republic of Poland was supported internally by the Council of Ministers.

Despite the emerging diverse concepts of the further development of the European Union noticed by the President of the Republic of Poland and the risk of weakening the cohesion of Member States, which is noticeable due to growing internal and external tensions, the European Union remains an important partner for Poland. In this area of international relations, the possibilities of the President of the Republic of Poland's activities under the so-called soft politics or lobbying in European political spheres.

In the European system, the President of the Republic of Poland has the possibility to actually act to strengthen Poland's defense potential. It does so by supporting the strengthening of political, military and industrial-defense cooperation with the most important European partners in the bilateral formula, as well as within the framework of the EU Common Security and Defense Policy. It is worth recalling the involvement of the Polish authorities, including the President of the Republic of Poland, in the EU PESCO (Permanent Structured Cooperation) project. Activities of the President of the Republic of Poland for the development of NATO-EU cooperation, incl. in terms of standardizing standards and improving infrastructure and military mobility in Europe, it strengthens the synergy of activities of both organizations, increasing the level of Poland's security. Thus, the President of the Republic of Poland indirectly contributes to the development of the EU security system and its complementary nature to the North Atlantic Alliance. 
One of the goals indicated by the President of the Republic of Poland in the field of state security is to prevent divisions between the Member States of the European Union and to engage in the process of European integration. In this aspect, security in the eastern neighborhood is particularly important, including within the framework of the Eastern Partnership. For example, by strengthening the sovereignty and integrity of Ukraine, Georgia and the Republic of Moldova and supporting their aspirations to accession in the European and Euro-Atlantic structures. The President of the Republic of Poland also attaches great importance to the development of regional cooperation, including as part of the Bucharest Nine, the Visegrad Group, the Weimar Triangle, the Three Seas Initiative and cooperation with the countries of the Baltic Sea region. In recent years, the Three Seas project has been one of the most important areas of the President's activities. This form of European cooperation between the Baltic, Adriatic and Black Sea is supposed to be, apart from stimulating economic development, a form of strengthening regional security.

It can be noted that the President of the Republic of Poland adopts in his actions a broad concept of state security. For example, the President of the Republic of Poland in 2020, among his priority actions for security, indicated the energy sector, and in this context, the need to strengthen relations with EU partners. According to the President of the Republic of Poland, it is necessary for the expansion of the gas terminal in Swinoujście and the construction of the Baltic Pipe (a gas pipeline that will carry gas from the Norwegian Shelf through Denmark along the bottom of the Baltic Sea to Poland). Other priorities in the activities of the President of the Republic of Poland are environmental and health safety. These are initiatives supported by the President of the Republic of Poland at the EU forum, and are intended to increase state security.

The soft policy of the President of the Republic of Poland in the field of security includes strengthening the positive image of Poland and its cultural and economic potential. It is an element of strengthening the state's position with the use of public and cultural diplomacy and social communication technology.

To sum up, the general powers of the President of the Republic of Poland in the field of state security seem to be weakened in the EU aspect. The importance of the President of the Republic of Poland in the legislative process and his legislative initiative is diminishing. After Poland's accession to the EU, the proportions of domestic law to the EU law changed. Moreover, there is the principle of the primacy of EU law. 
The President of the Republic of Poland also has no legislative initiative on the EU forum and no real possibility of influencing the EU legislative process. Also, the presidential veto is not effective under EU law. The President of the Republic of Poland only has to control the constitutionality of EU law through the Constitutional Tribunal. However, there is no legal basis for reacting in the event that the EU and its bodies intrude on competences that have not been delegated to them or will treat their competences extensively. The President of the Republic of Poland has a general obligation to cooperate with the Council of Ministers in European affairs, and there is also a clear asymmetry of competences between the members of the executive in this respect. There is still a lack of clear indications as to how the President of the Republic of Poland is to perform his constitutional functions in the field of state security in the EU. This problem should be among the essential de lege ferenda postulates.

It seems that in the current legal and political solutions, the only significant instrument that may be used by the President of the Republic of Poland as part of the implementation of his constitutional obligations, especially those related to state security, is the refusal or postponement of ratification of an international agreement (EU treaties). There is no strictly defined regime in this regard. However, it should be taken into account that the intention of the legislator was to minimize the importance of the President of the Republic of Poland in the sphere of foreign policy, and by refusing or postponing the ratification of an international agreement, the President of the Republic of Poland may increase his role in conducting foreign policy. This can cause both political tensions and can be ambiguously assessed in legal and axiological terms. It seems, however, that this is one of the most important factors increasing the political position of the President of the Republic of Poland in terms of the functioning of the state in the European Union and the ability of this authority to carry out tasks related to security. At the same time, it should be emphasized that the President of the Republic of Poland, as the head of state, can also function in the political system of the EU and act effectively to strengthen the security of the Polish state. 


\section{Bibliography}

Banaszak B., Ratyfikacja umowy międzynarodowej, [in:] W. Skrzydło, P. Grabowska, R. Grabowski (eds.), Konstytucja Rzeczypospolitej Polskiej. Komentarz encyklopedyczny, Warsaw 2009.

Garlicki L., Polskie prawo konstytucyjne. Zarys wykładu, Warsaw 2019.

Grzybowski M., Role ustrojowe Prezydenta RP w kontekście członkostwa w Unii Europejskiej, «Państwo i Prawo» 2004, no. 7.

Grzybowski M., Wtadza wykonawcza w Rzeczpospolitej Polskiej w warunkach członkostwa w Unii Europejskiej (wybrane zagadnienia), [in:] M. Kruk, J. Wawrzyniak (eds.), Polska $w$ Unii Europejskiej, Warsaw 2005.

Jaskiernia J., Funkcje Konstytucji RP $w$ dobie integracji europejskiej i radykalnych przemian politycznych, Torun 2020.

Kruk M., Tryb przystapienia Polski do Unii Europejskiej i konsekwencje członkostwa dla funkcjonowania organów państwa, [in:] K. Wójtowicz (ed.), Otwarcie Konstytucji RP na prawo międzynarodowe i procesy integracyjne, Warsaw 2006.

Mażewski L., Prowadzenie polityki zagranicznej w Rzeczypospolitej Polskiej, «Ruch Prawniczy, Ekonomiczny i Socjologiczny» 2009, no. 3.

Piotrowski R., W sprawie kompetencji Prezydenta RP „w stosunkach zewnettrznych”, [in:] J. Wawrzyniak, M. Laskowska (eds.), Instytucje prawa konstytucyjnego $w$ dobie integracji europejskiej, Warsaw 2009.

Słomka T., Prezydent Rzeczypospolitej po 1989 roku. Ujęcie porównawcze, Warsaw 2005.

Spryszak K., Wyrażenie zgody na ratyfikację umowy międzynarodowej - model konstytucyjny i uwarunkowania jego realizacji, «Przegląd Konstytucyjny» 2019, no. 3. 